\title{
Cultura de Embriões até o Estágio de Blastocisto: Comparação entre 0 Uso de Meios Seqüenciais e de Co-Cultura
}

\author{
Embryo Culture to Blastocyst Stage: \\ Comparison Using Sequential Medium and Coculture
}

Carlos Gilberto Almodin, Vania Cibele Minguetti-Câmara, Lis Andréa Cardoso Pereira

\section{RESUMO}

Objetivos: comparar o desenvolvimento embrionário com o uso de dois métodos diferentes de cultura (meio seqüencial ou co-cultura em células Vero).

Métodos: foram incluidas 110 pacientes que tiveram ovócitos aspirados e submetidos à fertilização in vitro. Metade das pacientes teve seus embriões cultivados juntamente com células Vero e a outra metade em meio seqüencial G1:2/G2:2. Os embriões foram transferidos no dia 5 pós-fertilização, após avaliação morfológica, verificando-se a taxa de blastulação. A gravidez foi definida por meio de ultra-sonografia, verificando-se batimento cardíaco após a $13^{a}$ semana pós-transferência.

Resultados: a taxa de blastocistos expandidos encontrada em nosso estudo foi de 15,9\% e 14\% com células Vero e G1:2/G2:2, respectivamente. Com células Vero 36,0\% das pacientes engravidaram com taxa de implantação de 18,9\%. Quando se utilizou G1:2/G2:2 as taxas de gravidez e implantaçãoforam 28,9\% e 14,9\%, respectivamente. Em apenas 17 casos obtiveramse blastocistos após co-cultivo em células Vero, apresentando 76,5\% de taxa de gravidez e 63,0\% de implantação. Quando o cultivo foi em G1/G2 21 pacientes apresentaram blastocistos e as taxas de gravidez e implantação foram de 57,1 e 76,0\%, respectivamente.

Conclusão: não houve diferença significativa entre as taxas de gravidez ou implantação nos 2 tipos de cultivo. Nos casos em que blastocistos expandidos foram transferidos, as taxas de implantação e gravidez aumentaram com ambos os tipos de cultivo. Nestas pacientes, independente do tipo de cultivo utilizado, um número maior de ovócitos foi obtido, o que nos leva a pensar que não apenas as condições de cultura influenciam as taxas de implantação e gravidez, mas a qualidade dos óvulos também é importante, pois as "boas respondedoras" tiveram melhores resultados.

PALAVRAS-CHAVE: Fertilização in vitro. Infertilidade. Cultura de embriões.

Introdução

As condições de cultura de embriões humanos têm sido responsabilizadas como principal fator pelas baixas taxas de implantação e gravidez ${ }^{1}$. É difícil avaliar morfologicamente os efeitos deletérios que os meios de cultura exercem sobre os embriões. Na tentativa de avaliar a viabilidade dos

Materbaby - Reprodução Humana e Genética, Maringá, PR Correspondência:

Carlos Gilberto Almodin

Av. XV de Novembro, 1232

87013-230 - Maringá - PR embriões, muitos autores têm realizado a transferência para o útero no dia 5 pós-fertilização em estágio de blastocisto, sendo sugerido por alguns que isto só é válido nos casos em que se tem grande número de embriões, ao passo que outros apóiam a idéia de que a sincronização do embrião com o trato feminino é importante ${ }^{2,3}$. O principal problema relacionado à transferência de blastocistos é conseguir condições de cultura adequadas para suportar o desenvolvimento dos embriões até o dia 5 ou 6 após a fertilização.

Há poucos anos foi focada atenção nos benefícios que a co-cultura, principalmente nos casos de falhas sucessivas de implantação, pudesse ofe- 
recer. Guerin e Nicolet ${ }^{4}$ relataram os resultados de 11 grupos franceses, que após realizarem 1603 culturas de embriões com outras células conseguiram taxa de blastulação de $41,8 \%$ e taxas de gravidez e implantação de 32,9 e 24,8\%, respectivamente. Estes grupos utilizaram as células Vero, mas outros tipos celulares como células epiteliais de oviduto bovino e humano ${ }^{5,6}$ ou fibroblastos uterinos bovinos ${ }^{7}$ parecem ter o mesmo efeito quanto a melhorar o desenvolvimento do embrião.

Outros autores renovaram as esperanças de melhores taxas de gravidez com o advento dos meio de cultura seqüenciais livres de soro, formulados para cultura do zigoto até a fase de blastocisto. Recentemente, estudos sobre a fisiologia e metabolismo do embrião levaram ao uso de meios mais próximos às necessidades dos embriões. As mudanças na composição dos meios incluem modificações no conteúdo de carboidratos e aminoácidos, entre outras. Estes meios elevaram as taxas de formação de blastocisto a níveis superiores a 50\% no dia 5 de desenvolvimento, e taxas de gravidez e implantação superiores a 60 e 40\%, respectivamente $^{3}$.

Ainda existe muita controvérsia entre os autores quanto às melhores condições de cultura. Este estudo tem o intuito de comparar os resultados da utilização de células Vero e meios seqüencias no cultivo de embriões in vitro.

\section{Pacientes e Métodos}

Este estudo envolveu 110 pacientes com idade entre 23 a 45 anos, que durante o período de fevereiro de 1999 a julho de 2000 procuraram a Clínica Materbaby com infertilidade e foram indicadas para fertilização in vitro. Foram realizados 110 ciclos, sendo subdivididos aleatoriamente em dois grupos de 55 ciclos cada. A inclusão das pacientes no estudo ocorreu após consentimento informado prévio. Estas pacientes tiveram seus embriões co-cultivados em células Vero, células de cápsula renal de macacos Rhesus (Grupo 1) ou mantidos em meio seqüencial (Grupo 2), sendo os grupos determinados por sorteio aleatório, independente de idade ou causa da infertilidade. A causa da infertilidade em 53 casos foi o fator masculino. Nos casos restantes, as causas de infertilidade feminina incluíram endometriose (12), fator tubário (14), esterilidade sem causa aparente (29 casos) e 4 casos de falência ovariana, que utilizaram doação de óvulos.

A estimulação ovariana foi iniciada após bloqueio hipofisário com acetato de leuprolida (Lupron, TAP Pharmaceutical, Abbott Laboratories,
Chicago, IL, USA), 0,15 mL/dia, iniciado entre o vigésimo primeiro e o vigésimo terceiro dia do ciclo menstrual e mantido até o início da menstruação seguinte. No terceiro dia de sangramento era iniciada a indução, com redução do Lupron para $0,05 \mathrm{~mL} /$ dia, e a estimulação ovariana era iniciada com hormônio folículo-estimulante (Metrodin, Serono, São Paulo, SP, Brasil) na dose de 150-225 UI/dia ou gonadotrofina menopausal humana (Menogon, Ferring, São Paulo, SP, Brasil), 75-225 UI/dia. O crescimento folicular foi monitorado somente por ultra-sonografia endovaginal. Foi administrada gonadotrofina coriônica humana (HCG, 10.000 UI, Profasi, Serono) quando pelo menos 3 folículos com $20 \mathrm{~mm}$ de diâmetro foram observados. Os ovócitos foram aspirados 34-36 horas após a injeção de HCG usando punção ovariana transvaginal guiada pelo ultra-som.

Os ovócitos colhidos foram lavados em D-PBS (Gibco Laboratories, Grand Island, NY, USA), transferidos para placas contendo meio de cultura Ménézo B2 (Laboratorie CCD, Paris, França) e mantidos em incubadora (Forma, modelo 3159) a $37^{\circ} \mathrm{C}$, com atmosfera contendo $5 \%$ de $\mathrm{CO}_{2}$ e umidade de $97 \%$. O sêmen foi preparado por meio de gradiente descontínuo de Percoll (55/90\%, Pharmacia, Uppsala, Sweden). Nos casos de infertilidade por fator masculino os ovócitos foram submetidos à injeção intracitoplasmática. Tal procedimento era realizado 3 a 6 horas após a coleta dos ovócitos, quando estes eram desnudados com o auxílio de hialuronidase (H-3757, Sigma, St. Louis, MO, USA). Nos casos nos quais os parâmetros do sêmen eram adequados foi realizada a inseminação dos ovócitos com 100.000 espermatozóides $/ \mathrm{mL}$.

Guando era realizada a micromanipulação, utilizava-se microscópio invertido Diaphot 300 (Nikon, Japão) com contraste de fase Hoffman, sob aumento de 400X. O microscópio era equipado com micromanipuladores hidráulicos MMO-204D e injetores IM6 (Narishige, Tokyo, Japan). Durante o procedimento um único espermatozóide era identificado, imobilizado e aspirado a partir de uma gota de meio de cultura tamponado HTF (Irvine Scientific, Santa Ana, CA, USA) contendo polivinilpirrolidona (Irvine Scientific). Os ovócitos foram mantidos por uma pipeta de sustentação, enquanto o espermatozóide era injetado.

A confirmação da fecundação era verificada 15 a 18 horas após a fertilização e os embriões com 2 pró-núcleos (PN) eram depositados sobre a monocamada de células Vero cultivadas em meio de cultura Ménézo B2 com 10\% de soro sintético (Irvine) ou em meio G1:2 com soro albumina humana a 5\% (Irvine). O congelamento dos embriões em pró-núcleo foi realizado segundo protoco- 
lo proposto por Check et al. ${ }^{8}$, não obedecendo a um padrão, sendo realizado segundo o histórico de cada paciente.

As placas contendo células Vero eram preparadas previamente, sendo descongeladas ou repicadas a partir de outros frascos mantidos em estufa. Quando descongeladas, as células eram lavadas e diluídas de modo a obter-se concentração de 200.000 a $400.000 / \mathrm{mL}$. O repique era realizado com o auxílio de tripsina (T-8642, Sigma) que descolava as células do fundo do frasco, sendo posteriormente lavadas e diluídas adequadamente. Eram mantidas a $37^{\circ} \mathrm{C}$ e $5 \%$ de $\mathrm{CO}_{2}$, alcançando a confluência de células dentro de 48 horas.

Os embriões eram mantidos em co-cultivo até o dia 3 pós-fertilização, quando sofriam troca de cerca de $70 \%$ de seu meio de cultura por meio novo, sendo então mantidos até o dia 5 . A transferência uterina somente era realizada neste dia, quando pelo menos um dos embriões tivesse atingido o estágio de blastocisto. Caso contrário, eles eram mantidos por mais um dia em cultura.

Os embriões colocados em meios seqüências permaneciam em placas contendo $50 \mu \mathrm{L}$ de meio G1:2 cobertas com óleo mineral até o dia 3 , quando eram transferidos para $50 \mu \mathrm{L}$ de meio G2:2 com soro albumina humana $5 \%$, permanecendo até o dia 5. Quando não havia a presença de blastocisto, trocava-se o meio G2:2 e a transferência era realizada no dia 6.

Nos 2 grupos eram selecionados para a transferência apenas os embriões que não apresentassem sinal de bloqueio do desenvolvimento. Quando havia mais de 3 blastocistos para a transferência, o restante era congelado, segundo protocolo proposto por Ménézo et al. ${ }^{9}$.

A fase lútea foi suplementada com $50 \mathrm{mg} /$ IM/dia de progesterona, $16 \mathrm{mg} / \mathrm{dia} \mathrm{de}$ metilprednisolona e $80 \mathrm{mg} / \mathrm{dia}$ de ácido acetilsalicílico. A gravidez foi definida pela presença de gestação viável e batimento cardíaco presentes após a $13^{\mathrm{a}}$ semana pós-tranferência.

As variáveis qualitativas foram representadas por freqüência absoluta (n) e relativa (\%) e a diferença entre os dois grupos foi verificada pelo teste do $\chi^{2}$. As variáveis quantitativas foram representadas por média e desvio padrão (DP) e os dois grupos foram comparados em relação a essas variáveis pelo teste $t$ de Student para amostras independentes. Adotou-se o nível de significância de $0,05(\alpha=5 \%)$. Niveis descritivos (p) inferiores a esse valor foram considerados significantes e marcadas com *.

\section{Resultados}

Das 55 pacientes incluídas no Grupo 1, foram colhidos 435 ovócitos e destes, 362 (83,2\%) foram inseminados e/ou fertilizados. Os restantes não estavam em metáfase II (MII) ou apresentavam alterações morfológicas. Após 18 h da fertilização foram observados 259 embriões (71,5\%), sendo $182(70,3 \%)$ mantidos em co-cultivo por 5 a 6 dias e $77(29,7 \%)$ congelados quando apresentavam 2 PN. Foram obtidos 50 blastocistos/zigoto, atingindo uma taxa de blastulação de 27,5\%, sendo que 29 destes (15,9\%) eram blastocistos expandidos (BE). Apenas 148 embriões foram transferidos após o término da co-cultura, para 50 pacientes, das quais 18 engravidaram $(36,0 \%)$. Em 3 casos não houve embriões viáveis para transferência e em 2 casos não houve recuperação dos ovócitos. A taxa de implantação foi de $18,9 \%$, pois 28 sacos gestacionais com batimento cardíaco foram observados à ultra-sonografia (Tabela 1).

Tabela 1 - Comparação entre 0 uso de G1/G2 e células Vero no cultivo dos embriões.

\begin{tabular}{|c|c|c|}
\hline & Células Vero & G1/G2 \\
\hline Número de pacientes & 55 & 55 \\
\hline Média \pm DP da idade em anos & $33,2 \pm 4,9$ & $32,5 \pm 5,2$ \\
\hline Média \pm DP do nº de ovócitos colhidos & $7,9 \pm 6,2$ & $6,7 \pm 5,0$ \\
\hline Média \pm DP do $n^{\circ}$ de embriões com 2 PN & $4,7 \pm 4,3$ & $3,9 \pm 3,3$ \\
\hline Média \pm DP do nº de embriões cultivados até D5 ou D6 & $3,3 \pm 2,0$ & $3,8 \pm 3,1$ \\
\hline Média \pm DP do $n^{\circ}$ de embriões transferidos & $3,0 \pm 1,6$ & $2,8 \pm 1,8$ \\
\hline Taxa de fertilização (\% embriões com 2PN/ovócito em MII) & 71,5 & 70,2 \\
\hline Taxa de blastocistos desenvolvidos de 2PN (\%) & 27,5 & 37,7 \\
\hline Taxa de BE desenvolvidos de 2 PN (\%) & 15,9 & 14,0 \\
\hline Taxa de gravidez clínica/transferência (\%) & 36,0 & 28,9 \\
\hline Taxa de implantação (\% por saco gestacional) & 18,9 & 14,8 \\
\hline
\end{tabular}

$\mathrm{PN}=$ pró-núcleos; $\mathrm{BE}$ = blastocistos expandidos; $\mathrm{MII}=$ metáfase II. 
Em 17 pacientes obtiveram-se embriões no estágio de BE após co-cultivo (Grupo 1). Nestas pacientes foram colhidos 220 ovócitos, sendo 191 (86,8\%) em MII, e fertilizados 128 (67,0\%). Os 79 embriões co-cultivados desenvolveram 29 blastocistos expandidos, sendo transferidos 27 , pois
2 foram congelados. Treze destas pacientes engravidaram $(76,5 \%)$ e foram observados 17 sacos gestacionais com batimento cardíaco, sendo a taxa de implantação 63,0\% se considerarmos apenas os BE transferidos (Tabela 2).

Tabela 2 - Comparação entre G1/G2 e células Vero nas pacientes que tiveram desenvolvimento a blastocisto expandido.

\begin{tabular}{lcc}
\hline & Células Vero & G1/G2 \\
\hline Número de pacientes (\%) & $17(30,9 \%)$ & $21(38,2 \%)$ \\
Média \pm DP da idade em anos & $30,6 \pm 4,7$ & $31,6 \pm 4,9$ \\
Média \pm DP do $n^{\circ}$ de ovócitos colhidos & $12,1 \pm 5,7$ & $10,2 \pm 5,2$ \\
Média \pm DP do $n^{\circ}$ de embriões com 2 PN & $7,6 \pm 4,5$ & $6,5 \pm 2,8$ \\
Média \pm DP do $n^{\circ}$ de embriões cultivados até D5 ou D6 & $4,6 \pm 1,4^{*}$ & $1,3 \pm 2,7^{*}$ \\
Média \pm DP do $n^{\circ}$ de BE desenvolvidos de 2 PN & 67,0 & $1,4 \pm 0,8$ \\
Taxa de fertilização (\% embriões com 2 PN/ovócitos MII) & 75,1 \\
Taxa de gravidez clínica/transferência (\%) & 76,5 & 57,1 \\
Taxa de implantação/BE transferido (\% por saco gestacional) & 76,0 \\
\hline
\end{tabular}

* $p<0,05$

$\mathrm{PN}=$ pró-núcleos; $\mathrm{BE}=$ blastocistos expandidos; MII = metáfase II.

No Grupo 2 foram incluídas também 55 pacientes, obtendo-se 305 ovócitos em MII $(82,2 \%)$, que foram inseminados ou submetidos a injeção intracitoplasmática de espermatozóide (ICSI), e os 66 ovócitos restantes $(17,8 \%)$ foram descartados. Foram obtidos 214 embriões $(70,2 \%)$ e apenas 7 foram congelados em 2 PN. Dos 207 embriões cultivados, 78 chegaram ao estágio de blastocisto (37,7\%), sendo 29 destes blastocistos expandidos (14,0\%). Foram transferidos 128 embriões, sendo estes transferidos para 45 pacientes. Destas, 13 engravidaram (28,9\%). Em 6 casos houve falha de coleta de ovócitos, em 2 casos falha de fertilização e em 2 casos os embriões pararam o desenvolvimento muito precocemente. Foram observados 19 sacos gestacionais com batimento cardíaco à ultrasonografia, sendo a taxa de implantação de $14,8 \%$.

Nas 21 pacientes que tiveram $\mathrm{BE}$ após cultivo em G1:2/G2:2, foi obtido um total de 214 ovócitos, com $181(84,6 \%)$ em MII. A taxa de fertilização foi de 75, 1\% (136/181). Dos 132 embriões que permaneceram em cultivo, 29 desenvolveram-se até o estágio de $\mathrm{BE}$, sendo 25 destes transferidos e o restante congelado. A taxa de gravidez foi de 57, $1 \%$, pois 12 pacientes engravidaram. A taxa de implantação por BE transferido foi de 76,0\%, com 19 sacos gestacionais com batimento cardíaco.

\section{Discussão}

$\mathrm{Na}$ tentativa de obter embriões com maior chance de implantação, muitos autores têm utilizado meios seqüênciais no cultivo destes. A idéia do meio seqüencial baseia-se na divisão do período pré-implantacional em 2 fases. A primeira corresponde ao estágio de clivagem do embrião, caracterizado por niveis baixos de biossíntese, baixa capacidade respiratória e limitada capacidade de utilizar glicose como fonte de energia, pois a função mitocondrial está diminuída. Já no período pós-compactação aumentam as taxas de biossintese, assim como a capacidade respiratória e a habilidade para utilizar glicose ${ }^{1}$. De acordo com as mudanças fisiológicas é importante considerar mudanças nas formulações dos meios.

A ocorrência do bloqueio de desenvolvimento em várias espécies coincide com a transição do estágio do oviduto para o útero. Embriões de hamster entram no útero com 4-8 células, correspondendo esta fase ao bloqueio de desenvolvimento in vitro. Embriões de coelho permanecem no oviduto até tornarem-se mórulas, a mesma etapa na qual o bloqueio de desenvolvimento pode ser induzido in vitro. O bloqueio de desenvolvimento também ocorre em mórula, em embriões de gato, o mesmo estágio no qual eles entram no útero ${ }^{10}$. Análises do fluido do oviduto e do útero ao longo do ciclo hormonal revelam mudanças na concentração de carboidratos tanto dentro do ciclo como entre o oviduto e o útero. Gardner e Lane $^{2}$ verificaram que os niveis de glicose no oviduto são mais baixos quando o ovócito/pré-embrião estão presentes $(0,5 \mathrm{mM})$, ao passo que o piruvato está aumen- 
tado $(0,32 \mathrm{mM})$ e no útero a glicose alcança um pico de $3,15 \mathrm{mM}$ e o piruvato está bem diminuído $(0,1 \mathrm{mM})$. Entretanto, deve-se levar em consideração que o ovócito e o pré-embrião são circundados por células do cumullus que são muito ativas metabolicamente e consomem glicose liberando piruvato e lactato. Além disso, é importante considerar que o embrião de 2 células possui um transportador específico para a glicose, indicando alguma função fisiológica para esta hexose, talvez outra que não como fonte de energia. O desvio da utilização da glicose para outras vias pode levar à biossíntese de importantes anabólitos para o embrião, e o caminho metabólico e nutrientes preferidos podem levar a vantagens no suporte do desenvolvimento do embrião in vitro. Importantes reguladores do metabolismo energético são os aminoácidos. Os aminoácidos essenciais não parecem conferir nenhum benefício ao embrião até o estágio de 8 células, e até podem resultar em perda de viabilidade ${ }^{2}$. Todos estes dados demonstrados a respeito do metabolismo do embrião justificam a utilização dos meios seqüenciais.

Schoolcraft et al. ${ }^{11}$ mostraram recentemente taxas de gravidez e implantação, com o uso de meios seqüenciais, superiores às obtidas com o uso de co-cultivo por outros autores. Nosso trabalho não mostrou diferença entre as taxas obtidas entre os dois tipos de cultivo. Há diferenças importantes entre o estudo de Schoolcraft et al. ${ }^{11}$ e o nosso. A primeira é que nós usamos o G1:2/G2:2 "comercial" no cultivo dos embriões, meio este que passou por transporte e provavelmente oscilações de temperatura que podem alterar a sua composição e causar danos aos embriões. Outra diferença relevante é que a média do número de zigotos/ paciente foi menor e menos constante $(4,0 \pm 3,3 \mathrm{x}$ $12,9 \pm 0,5)$ em nosso estudo. Isto ocorreu devido a diferenças no critério de inclusão e seleção de pacientes. Apenas as pacientes "boas respondedoras", com pelo menos 10 folículos $\geq 12 \mathrm{~mm}$ em diâmetro no dia da injeção do HCG, foram incluídas no estudo de Schoolcraft et al. ${ }^{11}$. Foram mantidas no estudo, também, somente as pacientes com 4 ou mais ovócitos fertilizados, pois as pacientes com 3 ou menos zigotos tiveram seus embriões transferidos no dia 3 de desenvolvimento, diferente de nosso estudo, em que todas as pacientes, mesmo com menos de 3 pré-embriões, tiveram a transferência no dia 5 pós-fertilização.

Pode-se verificar em nosso estudo que nas pacientes que tiveram blastocistos expandidos a taxa de gravidez e implantação foi superior (Tabela 2) à estatística geral. Deve-se observar no entanto que estas pacientes tiveram número maior de ovócitos colhidos, e portanto de embriões em PN, tanto com células Vero como com G1:2/G2:2
(Tabela 2). Se considerarmos apenas as pacientes nas quais se obtiveram mais que 7 ovócitos em MII, observamos que $65 \%$ das pacientes com G1:2/G2:2 tiveram blastocistos expandidos e apenas 39\% tiveram este êxito quando consideramos todas as pacientes. A taxa de pacientes que tiveram blastocisto expandido com o uso de células Vero também variou de 33 para 54\% nas pacientes com mais de 7 ovócitos em MII (dados não mostrados). Quando utilizamos células Vero, deixamos um número menor de embriões em cultivo (o restante foi congelado em PN), mas mesmo assim não houve diferença significativa no número de blastocistos expandidos obtidos entre os dois grupos. Isto nos leva a acreditar que a qualidade dos ovócitos, e não apenas o número, interfere com a obtenção de blastocistos expandidos. Pode-se verificar então que quando incluímos pacientes "boas respondedoras" nossa taxa de gravidez e implantação sofre um incremento significativo, independente do procedimento de cultivo utilizado.

Acredita-se que as células somáticas modifiquem o meio de cultura de uma maneira consistente com a fisiologia do embrião. Os sistemas de co-cultura alteram o meio, seja pela secreção de substâncias importantes ao desenvolvimento do embrião, como pela extração de impurezas ou redução de níveis de nutrientes do meio ${ }^{12}$. Esta redução pode ser inclusive nos níveis de glicose, o que é consistente com a teoria do uso dos meios seqüenciais. Mas um detalhe importante é que estas células têm sido utilizadas mesmo durante o período pós-compactação, quando a necessidade de glicose parece ser maior. Nas pacientes que tiveram transferência em estágio de blastocisto expandido, foi observada tendência a uma maior taxa de implantação quando o meio G1:2/G2:2 foi utilizado (Tabela 2), sugerindo melhor qualidade destes blastocistos, mesmo não bem evidenciada morfologicamente, em relação ao co-cultivo. Além disso, comparando-se o resultado entre transferência no dia 3 ou dia 5 pós-fertilização após o uso de células Vero se não encontraram diferenças significativas nas taxas de gravidez ou implantação ${ }^{13}$. O mesmo tem sido evidenciado quando se utilizam meios seqüenciais, tendo muitos autores optado por cultura de longa duração apenas nos casos em que se tem um número grande de embriões para selecionar aqueles a serem transferidos.

Grande importância tem sido dada ao cocultivo devido à secreção de fatores de crescimento pelas células. Kurachi et al. ${ }^{14}$ determinaram que a presença de EGF e TGF- $\alpha$ são importantes para o desenvolvimento de embriões de camundongo. A adição de anticorpos monoclonais para os receptores dos mencionados fatores de crescimento reduziram o desenvolvimento a blastocistos, en- 
tão indiretamente sugerindo que estes fatores são necessários. Sargent et al. ${ }^{15}$ sugerem a produção de meios de cultura definidos, sem soro e suplementados com fatores de crescimento. A adição de fatores ao meio de cultura promove o desenvolvimento de blastocistos in vitro de um grande número de espécies ${ }^{16-18}$. Dunglison et al. ${ }^{19}$ aumentaram a formação de blastocistos humanos de 18,4 para $43,6 \%$ após a adição de LIF ao meio (1000 $\mathrm{UI} / \mathrm{mL}$ ). Este incremento às taxas de formação de blastocistos utilizando o LIF também foi observado por outros autores ${ }^{20,21}$, mas existem controvérsias quanto à melhoria no desenvolvimento embrionário ${ }^{22}$. Martin et al. ${ }^{23}$ cultivaram embriões humanos em um meio modificado, com níveis reduzidos de glicose e lactato e adição de aminoácidos essenciais, aumentando a taxa de formação de blastocistos de 40,7 para $45,5 \%$, mas na presença de $1 \mathrm{nM}$ de "heparin-binding epidermal growth factor" (HB-EGF) a taxa foi aumentada para $65,4 \%$ e com $100 \mathrm{nM}$ de HB-EGF foi para 71,0\%, sendo que $81 \%$ destes embriões alcançaram o "hatching". Não houve diferença na qualidade dos blastocistos, entretanto são necessárias mais investigações quanto à normalidade destes embriões antes do uso clínico ${ }^{23}$. Além dos fatores de crescimento e/ ou citocinas, uma variedade de lipídeos, incluindo ácidos graxos livres, triglicerídeos e fosfolipídeos, têm sido sintetizados e liberados no meio de cultura pela co-cultura, além de enzimas antioxidantes que podem aumentar o desenvolvimento embrionário pela metabolização de radicais livres ${ }^{12}$.

Apesar dos grandes avanços nas técnicas de reprodução humana nos últimos anos, as taxas de gravidez ainda são insatisfatórias e estudos ainda serão necessários para elucidar melhor os aspectos fisiológicos e metabólicos dos embriões. Dividir as exigências metabólicas do embrião apenas em 2 fases, pré- e pós-compactação, talvez seja insuficiente. Quanto aos fatores de crescimento, talvez eles sejam necessários apenas em determinados estágios de desenvolvimento do embrião, e talvez possam causar efeitos deletérios se usados inapropriadamente. Um ponto parece ser de consenso entre os autores: a necessidade da transferência de embriões morfologicamente saudáveis, independentemente do estágio em que for feita a transferência. Pode-se comprovar pela Tabela 2 que quando as pacientes tiveram bons embriões para a transferência, ou seja, blastocistos expandidos, tiveram taxas de gravidez aumentadas, seja com o uso de células Vero ou G1:2/G2:2. As taxas de implantação também aumentam, principalmente porque apenas embriões morfologicamente ideais foram transferidos.

\section{SUMMARY}

Purpose: to compare the embryonic development obtained with two different culture methods (sequential medium or coculture in Vero cells).

Methods: oocytes were recovered from 110 patients and submitted to in vitro fertilization. The embryos of half of the patients were co-cultured with Vero cells and the embryos of the other half were cultured in sequential G1:2/G2:2 medium for five days. The embryos were transferred on the 5 th day after fertilization after morphological evaluation for the determination of blastula formation rate. Pregnancy was defined by ultrasonography and a fetal heartbeat was determined 13 weeks after transfer.

Results: the expanded blastocyst rate found in our study was 15.9 and 14\% with Vero cells and G1:2/G2:2, respectively. With Vero cells $36.0 \%$ of patients became pregnant and the implantation rate was $18.9 \%$. When G1:2/G2:2 was used, the pregnancy and implantation rates were 28.9 and $14.9 \%$, respectively. Only 17 patients had blastocysts after coculture in Vero cells, with a $76.5 \%$ pregnancy rate and a $63.5 \%$ implantation rate. When embryos were cultured in $61 / G 2$, 21 patients presented blastocysts and the pregnancy and implantation rates were 57.1 and $76.0 \%$, respectively. Conclusion: there was no significant difference in pregnancy or implantation rates between the 2 types of culture. When expanded blastocysts were transferred, the implantation and pregnancy rats increased with both culture types. In these patients, regardless of the type of culture used, a larger number of oocytes was obtained, suggesting that the implantation and pregnancy rates are affected not only by the culture conditions but also by the quality of the eggs, since "good responders" had better results.

KEY WORDS: In vitro fertilization. Infertility. Embryo culture.

\section{Referências}

1. Ménézo Y, Chouteau J, Guyader-Joly C, Veiga A. Sequential media: why and how? Contracept Fertil Sex 1999; 27:449-51.

2. Gardner DK, Lane M. Culture and selection of viable blastocysts: a feasible proposition for human IVF? Hum Reprod Update 1997; 3:367-82.

3. Gardner DK, Vella P, Lane M, Wagley L, Schlenker T, Schoolcraft WB. Culture and transfer of human blastocysts increases implantation rates and reduces the need for multiple embryo transfers. Fertil Steril 1998; 69:84-8.

4. Guerin JF, Nicolet B. Interest of co-cultures for embryos obtained by in vitro fertilization: a French collaborative study. Hum Reprod 1997; 12:1043-6. 
5. Bongso A, Ng SC, Fong CY, et al. Improved pregnancy rate after transfer of embryos grown in human fallopian tubal cell coculture. Fertil Steril 1992; 58:569-74.

6. Wiemer KE, Hoffman DI, Maxson WS, et al. Embryonic morphology and rate of implantation of human embryos following co-culture on bovine oviductal epithelial cells. Hum Reprod 1993; 8:97-101.

7. Wiemer $\mathrm{KE}$, Cohen J, Amborski GF, et al. In vitro development and implantation of human embryos following culture on fetal bovine uterine fibroblast cells. Hum Reprod 1989; 4:595-600.

8. Check JH, Hoover L, Nazari A, O’Shaughnessy A, Summers D. The effect of assisted hatching on pregnancy rates after frozen embryo transfer. Fertil Steril 1996; 65:254-7.

9. Ménézo Y, Nicollet B, Herbaut N, Andre D. Freezing cocultured human blastocysts. Fertil Steril 1992; 58:977-80.

10.Bavister BD. Culture of preimplantation embryos: facts and artifacts. Hum Reprod Update 1995; 1:91-148.

11.Schoolcraft WD, Gardner DK, Lane M, Schlenker T, Hamilton F, Meldrum DR. Blastocyst culture and transfer: analysis of results and parameters affecting outcome in two in vitro fertilization programs. Fertil Steril 1999; 72:604-9.

12.Wiemer KE, Cohen J, Tucker MJ, Godke RA. The application of co-culture in assisted reproduction: 10 years of experience with human embryos. In: Dale B, editor. Development of the Human Embryo in vitro. $1^{\text {st }}$ ed. Oxford: University Press; 1998. p.235.

13.Almodin CG, Pereira LA, Minguetti-Câmara VC. Cocultura de embriões humanos em células Vero e transferência em fase de blastocisto. Rev Bras Ginecol Obstet 1999; 21:409-15.

14.Kurachi H, Morishige K, Imai T, et al. Expression of epidermal growth factor and transforming growth factor-alpha in fallopian tube epithelium and their role in embryogenesis. Horm Res 1994; 41 Suppl 1:48-54.
15.Sargent IL, Martin KL, Barlow DH. The use of recombinant growth factors to promote human embryo development in serum-free medium. In: Dale B, editor. Development of the Human Embryo in vitro. $1^{\text {st }}$ ed. Oxford: University Press; 1998. p.239-48.

16. Paria BC, Dey SK. Preimplantation embryo development in vitro: cooperative interactions among embryos and role of growth factors. Proc Natl Acad Sci USA 1990; 87:4756-60.

17.Harvey MB, Kaye PL. Insulin like growth factor-1 stimulates growth of mouse preimplantation embryos in vitro. Mol Reprod Dev 1992; 31:195-9.

18.Palma GA, Muller M, Brem G. Effect of insulinlike growth factor-I (IGF-I) at high concentrations on blastocyst development of bovine embryos produced in vitro. J Reprod Fertil 1997; 110:347-53.

19.Dunglison GF, Barlow DH, Sargent IL. Leukaemia inhibitory factor significantly enhances the blastocyst formation rates of human embryos cultured in serum-free medium. Hum Reprod 1996; 11:191-6.

20.Michell MH, Swanson RJ, Hodgen GD, Oehninger $\mathrm{S}$. Enhancement of in vitro murine embryo development by recombinant leukemia inhibitory factor. J Soc Gynecol Invest 1994; 1:215-9.

21.Hsieh YY, Tsai HD, Chang CC, Hsu LW, Chang SC, Lo HY. Prolonged culture of human cryopreserved embryos with recombinant human leukemia inhibitory factor. J Assist Reprod Genet 2000; $17: 131-4$.

22.Jurisicova A, Ben-Chetrit A, Varmuza SL, Casper $\mathrm{RF}$. Recombinant human leukemia inhibitory factor does not enhance in vitro human blastocyst formation. Fertil Steril 1995; 64:999-1002.

23.Martin KL, Barlow DH, Sargent IL. Heparin-binding epidermal growth factor significantly improves human blastocyst development and hatching in serum-free medium. Hum Reprod 1998; 13:1645-52. 